\title{
Cave-dwelling pholcid spiders (Araneae, Pholcidae): a review
}

\author{
Bernhard A. Huber' \\ I Alexander Koenig Research Museum of Zoology, Adenauerallee 160, 53113 Bonn, Germany \\ Corresponding author: Bernhard A. Huber (b.huber@leibniz-zfmk.de)
}

Academic editor: O. Moldovan | Received 4 May 2018 | Accepted 29 May 2018 | Published 6 June 2018

http://zoobank.org/E3AD5959-82BF-4FF3-95C3-C4E7B1A01D97

Citation: Huber BA (2018) Cave-dwelling pholcid spiders (Araneae, Pholcidae): a review. Subterranean Biology 26: 1-18. https://doi.org/10.3897/subtbiol.26.26430

\begin{abstract}
Pholcidae are ubiquitous spiders in tropical and subtropical caves around the globe, yet very little is known about cave-dwelling pholcids beyond what is provided in taxonomic descriptions and faunistic papers. This paper provides a review based on a literature survey and unpublished information, while pointing out potential biases and promising future projects. A total of 473 native (i.e. non-introduced) species of Pholcidae have been collected in about 1000 caves. The large majority of cave-dwelling pholcids are not troglomorphic; a list of 86 troglomorphic species is provided, including 21 eyeless species and 21 species with strongly reduced eyes. Most troglomorphic pholcids are representatives of only two genera: Anopsicus Chamberlin \& Ivie, 1938 and Metagonia Simon, 1893. Mexico is by far the richest country in terms of troglomorphic pholcids, followed by several islands and mainland SE Asia. The apparent dominance of Mexico may partly be due to collectors' and taxonomists' biases. Most caves harbor only one pholcid species, but 91 caves harbor two and more species (up to five species). Most troglomorphic pholcids belong to two subfamilies (Modisiminae, Pholcinae), very few belong to Smeringopinae and Arteminae, none to Ninetinae. This is in agreement with the recent finding that within Pholcidae, microhabitat changes in general are concentrated in Modisiminae and Pholcinae.
\end{abstract}

\section{Keywords}

Spider, Araneae, Pholcidae, troglomorphism, subterranean

Copyright Bernhard A. Huber. This is an open access article distributed under the terms of the Creative Commons Attribution License (CC BY 4.0), which permits unrestricted use, distribution, and reproduction in any medium, provided the original author and source are credited. 


\section{Introduction}

The colonization of subterranean habitats has occurred many times independently in many groups of animals (White and Culver 2012). This change of habitat has often resulted in more or less conspicuous and convergent modifications, or troglomorphisms (Hüppop 2012, Christiansen 2012, Protas and Jeffery 2012, Liu et al. 2017). Similar selective regimes have resulted in similar modifications in distantly related taxa, making cave animals an ideal model system to study fundamental evolutionary mechanisms. Interestingly, however, many widespread patterns continue to be contentious or even mysterious. For example, many recent debates focus on the mechanism responsible for regressive evolution such as the reduction and loss of eyes (Culver and Wilkens 2000, Christiansen 2012, Klaus et al. 2013, Krishnan and Rohner 2016). An old but still unsettled question concerns the apparent higher diversity of troglomorphic animals in temperate rather than in tropical regions (Howarth 1980, Culver and Sket 2000, Deharveng and Bedos 2012). And quite mysterious is the fact that only certain groups in any major taxon have entered caves and adapted to subterranean life while close relatives present in the same region have not (e.g., 91\% of cave beetles are members of only two out of 166 beetle families; Moldovan 2012; see also Christiansen 2012).

Spider research has the potential to contribute significantly to these debates. Spiders are in several ways preadapted to life in caves. Many are nocturnal; most rely on mechanical and chemical rather than on visual stimuli; many groups are diverse in habitats that share certain characteristics with caves such as damp sheltered spaces or leaf litter; many spiders have a low energy demand and endure long periods of starvation; and most are generalist feeders (Foelix 2011, Mammola and Isaia 2017). As a result, spiders are among the most common inhabitants of terrestrial caves all over the world. According to Mammola and Isaia (2017) "around 1000 troglobiomorphic spiders have been classified as troglobionts". However, a recent overview of the Brazilian obligatory subterranean fauna found that over $50 \%$ of troglobionts available in collections remain undescribed (Galláo and Bichuette 2018), suggesting that the actual number is much higher. Whatever the species numbers, compared to some other major groups like isopods, amphipods, carabid and leiodid beetles, salamanders, and fish, subterranean spiders have rarely been studied in much detail or propagated as model organisms for particular questions concerning evolution in subterranean environments (for exceptions, see Mammola and Isaia 2017; Mammola et al. 2017).

Pholcidae, one of the major spider families in terms of described species (World Spider Catalog 2018), epitomize this situation. On one hand, representatives of Pholcidae are among the most common spiders in tropical and subtropical caves around the globe. Very few studies exist that quantify this dominance but a recent study by Souza Silva and Ferreira (2015) on the invertebrates in 15 caves in Espírito Santo (Brazil) may well reflect a global pattern: Pholcidae was the spider family represented in the highest number of caves (13), followed by Theridiidae and Ctenidae (11 each) and Oonopidae (9). On the other hand, almost nothing is known about cave-dwelling pholcids beyond what is provided in taxonomic descriptions and faunistic papers. The present paper is an effort to provide a first step in filling this gap by (1) summarizing 
the known information; (2) highlighting some emerging systematic and biogeographic patterns; and (3) proposing a list of easily accessible and promising open questions that will hopefully motivate more specific research.

\section{Material and methods}

The information summarized herein is largely taken from the taxonomic literature. In addition, data on 37 undescribed cave-dwelling species (eight of them troglomorphic) available in collections were added. The resulting table included all records of all species that have been reported from caves, i.e. also the epigean records of species that occasionally enter caves ('accidentals') or that are commonly found both outside and within caves. Excluded were ten synanthropic species, all of which are occasionally found in caves, in most cases presumably as a result of human introduction. The resulting table thus included only 'native', i.e. non-introduced species; it had 3100 entries. Table 1 is an excerpt from this table, listing only the species classified as troglomorphic.

Species were classified as troglomorphic (i.e. showing features associated with cave life) versus non-troglomorphic in order to avoid the unprovable designation of a species as troglobiont (obligatory cave dweller; as opposed to troglophile). In many cases, the classification of a species as troglomorphic or non-troglomorphic was unambiguous (eyes reduced or absent; very pale coloration compared to epigean relatives), but in several cases a clear distinction was not possible, especially when "long legs" and/or the loss of pigment were the only reported troglomorphisms. Some of the species in Table 1 are thus listed based on subjective assessments (by previous researchers or by me) rather than on a quantification of troglomorphy.

A further source of noise in the data comes from the definition of cave. I largely use the anthropocentric definition of caves as "a natural opening in the Earth, large enough to admit a human being, and which some human beings choose to call a cave" (White 1988). This is probably very close to, or congruent with, the definition implied in the taxonomic literature.

Most published records do not provide coordinates, and even some published coordinates are obviously wrong. This introduces a further source of error, even though I made an effort to georeference as many caves as possible and to verify published coordinates. For this I used a variety of online databases as well as Google Earth and direct information from collectors.

\section{Results}

\section{Spiders}

A total of 473 native pholcid species (including 37 undescribed species) have been found in caves. This represents approximately $25 \%$ of the species currently known to exist (i.e. 1662 described species + -300 undescribed species available in collections). 
Table I. Troglomorphic Pholcidae. The references refer to the descriptions of the troglomorphies.

\begin{tabular}{|c|c|c|}
\hline $\begin{array}{c}\text { Species } \\
\end{array}$ & Troglomorphy & Reference \\
\hline Anopsicus bolivari (Gertsch, 1971) & Long legs & Gertsch 1982 \\
\hline Anopsicus clarus Gertsch, 1982 & Pale, eyeless, long legs & Gertsch 1982 \\
\hline Anopsicus cubanus Gertsch, 1982 & Eyeless, long legs & Gertsch 1982 \\
\hline Anopsicus exiguus (Gertsch, 1971) & White, long legs & Gertsch 1982 \\
\hline Anopsicus grubbsi Gertsch, 1982 & Small eyes & Gertsch 1982 \\
\hline Anopsicus gruta (Gertsch, 1971) & $\begin{array}{c}\text { Pale, eyes essentially obsolete, scarcely visible as } \\
\text { pale vestiges, long legs }\end{array}$ & Gertsch 1971, 1982 \\
\hline Anopsicus jarmila Gertsch, 1982 & $\begin{array}{c}\text { Pale, long legs, essentially eyeless, with trivial } \\
\text { vestiges of eyes }\end{array}$ & Gertsch 1982 \\
\hline Anopsicus limpidus Gertsch, 1982 & Pale, long legs, eyes rudimentary, small, white & Gertsch 1982 \\
\hline Anopsicus lucidus Gertsch, 1982 & $\begin{array}{l}\text { Pale, long legs, eyes evanescent, essentially } \\
\text { obsolete, without pigment }\end{array}$ & Gertsch 1982 \\
\hline Anopsicus mckenziei Gertsch, 1982 & Long legs & Gertsch 1982 \\
\hline Anopsicus mirabilis Gertsch, 1982 & $\begin{array}{l}\text { Pale, long legs, eyes evanescent, reduced to } \\
\text { inconspicuous, unpigmented vestiges }\end{array}$ & Gertsch 1982 \\
\hline Anopsicus mitchelli (Gertsch, 1971) & Small eyes, long legs & Gertsch 1971, 1982 \\
\hline Anopsicus nebulosus Gertsch, 1982 & $\begin{array}{l}\text { Pale, essentially eyeless, trivial vestiges of eyes, } \\
\text { long legs }\end{array}$ & Gertsch 1982 \\
\hline Anopsicus niveus Gertsch, 1982 & Pale, eyeless, long thin legs & Gertsch 1982 \\
\hline Anopsicus pearsei Chamberlin \& Ivie, 1938 & $\begin{array}{c}\text { Essentially eyeless, widely spaced corneal } \\
\text { vestiges }\end{array}$ & Gertsch 1982 \\
\hline Anopsicus pecki Gertsch, 1982 & Pale, long thin legs, eyes small & Gertsch 1982 \\
\hline Anopsicus quatoculus Gertsch, 1982 & Posterior lateral eyes missing & Gertsch 1982 \\
\hline Anopsicus reddelli Gertsch, 1982 & Pale, eyes small & Gertsch 1982 \\
\hline Anopsicus silvai Gertsch, 1982 & Long legs & Gertsch 1982 \\
\hline Anopsicus soileanae Gertsch, 1982 & Pale, long legs & Gertsch 1982 \\
\hline $\begin{array}{l}\text { Anopsicus speophilus } \\
\text { (Chamberlin \& Ivie, 1938) }\end{array}$ & Pale, eyes small & Gertsch 1982 \\
\hline Anopsicus troglodytus (Gertsch, 1971) & Small eyes, long legs & Gertsch 1971, 1982 \\
\hline Anopsicus vinnulus Gertsch, 1982 & $\begin{array}{c}\text { Long legs, eyes evanescent, without pigment, } \\
\text { essentially obsolete }\end{array}$ & Gertsch 1982 \\
\hline Artema sp. n. "Om42" ${ }^{\dagger}$ & Pale, small eyes & Unpublished \\
\hline Aymaria floreana (Gertsch \& Peck, 1992) & Essentially eyeless & Gertsch and Peck 1992 \\
\hline Aymaria jarmila (Gertsch \& Peck, 1992) & $\begin{array}{l}\text { Essentially eyeless, without external indication } \\
\text { of lost eyes or with small white vestiges }\end{array}$ & Gertsch and Peck 1992 \\
\hline Belisana bantham Huber, 2005 & Only two eyes, pale & Huber 2005a \\
\hline Belisana khanensis Yao \& Li, 2013 & Eyes absent & Yao and Li 2013 \\
\hline Belisana pisinna Yao, Pham \& Li, 2015 & Pale, small eyes & Yao et al. 2015 \\
\hline Buitinga? sp. n. "Reun1” & Pale, eyeless & Unpublished \\
\hline Ciboneya antraia Huber \& Pérez, 2001 & Pale, long legs & Huber and Pérez 2001 \\
\hline Coryssocnemis clara Gertsch, 1971 & Pale, long legs & Gertsch 1973 \\
\hline Hoplopholcus sp. n. "Tur21" $\$$ & Pale & Unpublished \\
\hline Khorata jaegeri Huber, 2005 & Pale, small eyes & Huber 2005b \\
\hline Metagonia atoyacae Gertsch, 1971 & Pale, eyeless & Gertsch 1971 \\
\hline Metagonia bellavista Gertsch \& Peck, 1992 & Whitish, eyeless & Gertsch and Peck 1992 \\
\hline Metagonia sp. n. "Br15-153"| & Pale, very small eyes without pigment & Unpublished \\
\hline Metagonia chiquita Gertsch, 1977 & Eyeless & Gertsch 1977 \\
\hline Metagonia debrasi Pérez \& Huber, 1999 & Eyeless & Pérez and Huber 1999 \\
\hline $\begin{array}{l}\text { Metagonia diamantina Machado, Ferreira } \\
\& \text { Brescovit, } 2011\end{array}$ & Eyeless & Machado et al. 2011 \\
\hline
\end{tabular}




\begin{tabular}{|c|c|c|}
\hline Species & Troglomorphy & Reference \\
\hline Metagonia iviei Gertsch, 1977 & Pale, long legs & Gertsch 1977 \\
\hline Metagonia jamaica Gertsch, 1986 & Eyeless & Gertsch 1986 \\
\hline Metagonia jarmila Gertsch, 1973 & $\begin{array}{l}\text { Pale, eyes obsolete or of moderate size, without } \\
\text { pigment }\end{array}$ & Gertsch 1973 \\
\hline Metagonia joya Gertsch, 1986 & Eyeless & Gertsch 1986 \\
\hline Metagonia lepida Gertsch, 1986 & Eyeless & Gertsch 1986 \\
\hline Metagonia luisa Gertsch, 1986 & Eyeless & Gertsch 1986 \\
\hline Metagonia martha Gertsch, 1973 & Pale, rudimentary eyes without pigment & Gertsch 1973 \\
\hline Metagonia maya Chamberlin \& Ivie, 1938 & $\begin{array}{l}\text { Whitish, long-legged, evanescent eyes without } \\
\text { pigment }\end{array}$ & Gertsch 1977 \\
\hline Metagonia oxtalja Gertsch, 1986 & Eyeless & Gertsch 1986 \\
\hline Metagonia pachona Gertsch, 1971 & Pale, very small eyes & Gertsch 1971 \\
\hline Metagonia potiguar Ferreira et al., 2011 & Pale, small eyes & Ferreira et al. 2011 \\
\hline Metagonia puebla Gertsch, 1986 & $\begin{array}{l}\text { Essentially eyeless, eyes present as small whitish } \\
\text { vestiges }\end{array}$ & Gertsch 1986 \\
\hline Metagonia pura Gertsch, 1971 & Pale, eyeless & Gertsch 1971 \\
\hline Metagonia reederi Gertsch \& Peck, 1992 & Whitish, eyeless & Gertsch and Peck 1992 \\
\hline Metagonia tinaja Gertsch, 1971 & Pallid coloration, small eyes & Gertsch 1971 \\
\hline Metagonia tlamaya Gertsch, 1971 & Pale, eyeless & Gertsch 1971 \\
\hline Metagonia torete Gertsch, 1977 & Evanescent eyes, long legs & Gertsch 1977 \\
\hline $\begin{array}{l}\text { Metagonia yucatana } \\
\text { Chamberlin \& Ivie, } 1938\end{array}$ & Pale, very long legs & Gertsch 1977 \\
\hline Ossinissa justoi (Wunderlich, 1992) & Eyes very small & $\begin{array}{l}\text { Dimitrov and Ribera } \\
2005\end{array}$ \\
\hline $\begin{array}{l}\text { Paramicromerys megaceros } \\
\text { (Millot, 1946) }\end{array}$ & $\begin{array}{c}\text { Almost entirely unpigmented, very long legs, } \\
\text { small eyes }\end{array}$ & Millot 1946 \\
\hline Pholcus arcuatilis Yao \& Li, 2013 & Small eyes, pale & Yao and Li 2013 \\
\hline Pholcus baldiosensis Wunderlich, 1992 & Pale, reduced eyes & Wunderlich 1992 \\
\hline Pholcus caecus Yao, Pham \& Li, 2015 & Pale, "eyes absent" [vestiges visible in figures] & Yao et al. 2015 \\
\hline Pholcus corniger Dimitrov \& Ribera, 2006 & $\begin{array}{l}\text { "Total reduction of eyes" [vestiges visible in } \\
\text { figure] }\end{array}$ & $\begin{array}{l}\text { Dimitrov and Ribera } \\
2005\end{array}$ \\
\hline Pholcus diopsis Simon, 1901 & Pale, small eyes & Huber 2011 \\
\hline Pholcus dongxue Yao \& Li, 2017 & Pale, small eyes & Dong et al. 2017 \\
\hline Pholcus sp. n. "G044" " & Pale, small eyes & Unpublished \\
\hline Psilochorus concinnus Gertsch, 1973 & Long legs & Gertsch 1973 \\
\hline Psilochorus delicatus Gertsch, 1971 & Pale & Gertsch 1971 \\
\hline Psilochorus diablo Gertsch, 1971 & Pale, eyes reduced in size & Gertsch 1971 \\
\hline Psilochorus fishi Gertsch, 1971 & Pale & Gertsch 1971 \\
\hline Psilochorus murphyi Gertsch, 1973 & Long legs & Gertsch 1973 \\
\hline Psilochorus russelli Gertsch, 1971 & Pale & Gertsch 1971 \\
\hline Psilochorus tellezi Gertsch, 1971 & Long legs & Gertsch 1971 \\
\hline Spermophora falcata Yao \& Li, 2013 & Very small vestigial eyes & Yao and $\mathrm{Li} 2013$ \\
\hline Spermophora sp. n. "Deele466” \# & Eyeless & Unpublished \\
\hline $\begin{array}{l}\text { Spermophorides anophthalma Wunderlich, } \\
1999\end{array}$ & Pale, eyes with strongly reduced lenses & Wunderlich 1999 \\
\hline Spermophorides flava Wunderlich, 1992 & Pale, small eyes & Wunderlich 1992 \\
\hline $\begin{array}{l}\text { Spermophorides fuertecavensis Wunderlich, } \\
1992\end{array}$ & Pale, small eyes & Wunderlich 1992 \\
\hline $\begin{array}{l}\text { Spermophorides reventoni Wunderlich, } \\
1999\end{array}$ & Long legs, small eyes & Wunderlich 1992 \\
\hline Stygopholcus absoloni (Kulczynski, 1914) & Paler than epigean S. photophilus & Unpublished \\
\hline
\end{tabular}




\begin{tabular}{l|c|c}
\hline \multicolumn{1}{c|}{ Species } & Troglomorphy & Reference \\
\hline Stygopholcus sp. n. "Bal3" $\dagger \dagger$ & Paler than epigean S. photophilus & Unpublished \\
\hline Uthina sp. n. "Ind67” $¥ \ddagger$ & Long legs, small eyes & Unpublished \\
\hline Zatavua andrei (Millot, 1946) & Almost unpigmented & Millot 1946 \\
\hline Zatavua ankaranae (Millot, 1946) & Almost unpigmented & Millot 1946 \\
\hline Zatavua impudica (Millot, 1946) & Almost unpigmented & Millot 1946 \\
\hline
\end{tabular}

†Artema sp. n. "Om42": Oman, Ad Dakhiliyah, Al Ghubrat cave (ZMFK).

¥Buitinga? sp. n. "Reun1": Réunion, St. Paul, Grotte de la Tortue (ZFMK).

${ }^{\S}$ Hoplopholcus sp. n. "Tur21": Turkey, Mersin Prov., Aydıncık District, Aynalıgöl (Gilindere) Mağarası (ZFMK). | Metagonia sp. n. "Br15-153”: Brazil, Rio Grande do Norte, near Baraúna, Caverna dos Macacos (ZFMK). 'Pholcus sp. n. "G044": Cape Verde, Fogo, Cueva de Gancho (ZFMK).

\# Spermophora sp. n. "Deele466”: Indonesia, West Papua, Irian Jaya, Gua Nomokendik, Nambuktep Kokas (RMNH).

†' Stygopholcus sp. n. "Bal3": Species limits among cave-dwelling Stygopholcus are unclear. A revision is in preparation, and I currently recognize two species: S. absoloni (a putative senior synonym of S. skotophilus; mainly in Montenegro) and the unnamed species "Bal3" (mainly in southern Croatia and Bosnia and Herzegovina). 抽ina sp. n. “Ind67”: Indonesia, Sulawesi, South Sulawesi, Bantimurung, Gua Mimpi (ZFMK).

Of these, 86 are here considered to be troglomorphic (Fig. 1; Table 1). Troglomorphic species occur in 20 genera (of currently 77 genera), but a majority of them are representatives of just two genera: Metagonia Simon, 1893 and Anopsicus Chamberlin \& Ivie, 1938 (Fig. 2). Together with three further genera (Pholcus Walckenaer, 1805; Psilochorus Simon, 1893; Spermophorides Wunderlich, 1992), they contain $-75 \%$ of all troglomorphic pholcid species. This bias is even more extreme when considering only the 42 'strongly' troglomorphic species, i.e. those without eyes or with reduced eyes: 30 (71\%) are in the genera Metagonia and Anopsicus (Fig. 3). Most troglomorphic pholcid species are in Pholcinae and Modisiminae (Fig. 4); four weakly troglomorphic species are in Smeringopinae and Arteminae; none in Ninetinae.

Of the 473 pholcid species known from caves, 298 are known from caves only, i.e. have so far not been collected from epigean habitats; 64 species have the majority of records (i.e. 50-99\%) from caves; 111 species have less that 50\% of their records from caves (the ten synanthropic pholcid species would fall in this category too) (Fig. 5). Of the 298 species known from caves only, the large majority (234, i.e. $79 \%$ ) are known from a single cave (Fig. 6). Among the other 64 species are some that appear fairly widely distributed, including six troglomorphic species that are known from 5-11 caves each. Two of these troglomorphic species occur in several caves but these caves are all close together (Metagonia potiguar Ferreira et al., 2011: five caves within $10 \mathrm{~km}$; Aymaria jarmila (Gertsch \& Peck, 1992): six caves within $15 \mathrm{~km}$ ); the other four species cover large to very large areas (Metagonia tinaja Gertsch, 1971: nine caves within 50 km; Anopsicus quatoculus Gertsch, 1982: seven caves within 65 km; Anopsicus pearsei Chamberlin \& Ivie, 1938: five caves within $190 \mathrm{~km}$; Metagonia maya Chamberlin \& Ivie, 1938: 11 caves within $260 \mathrm{~km}$ ).

Few cave pholcids seem to be relicts, based on the apparent absence of epigean close relatives (cf. Grandcolas et al. 2014). Examples include (1) the four species of 

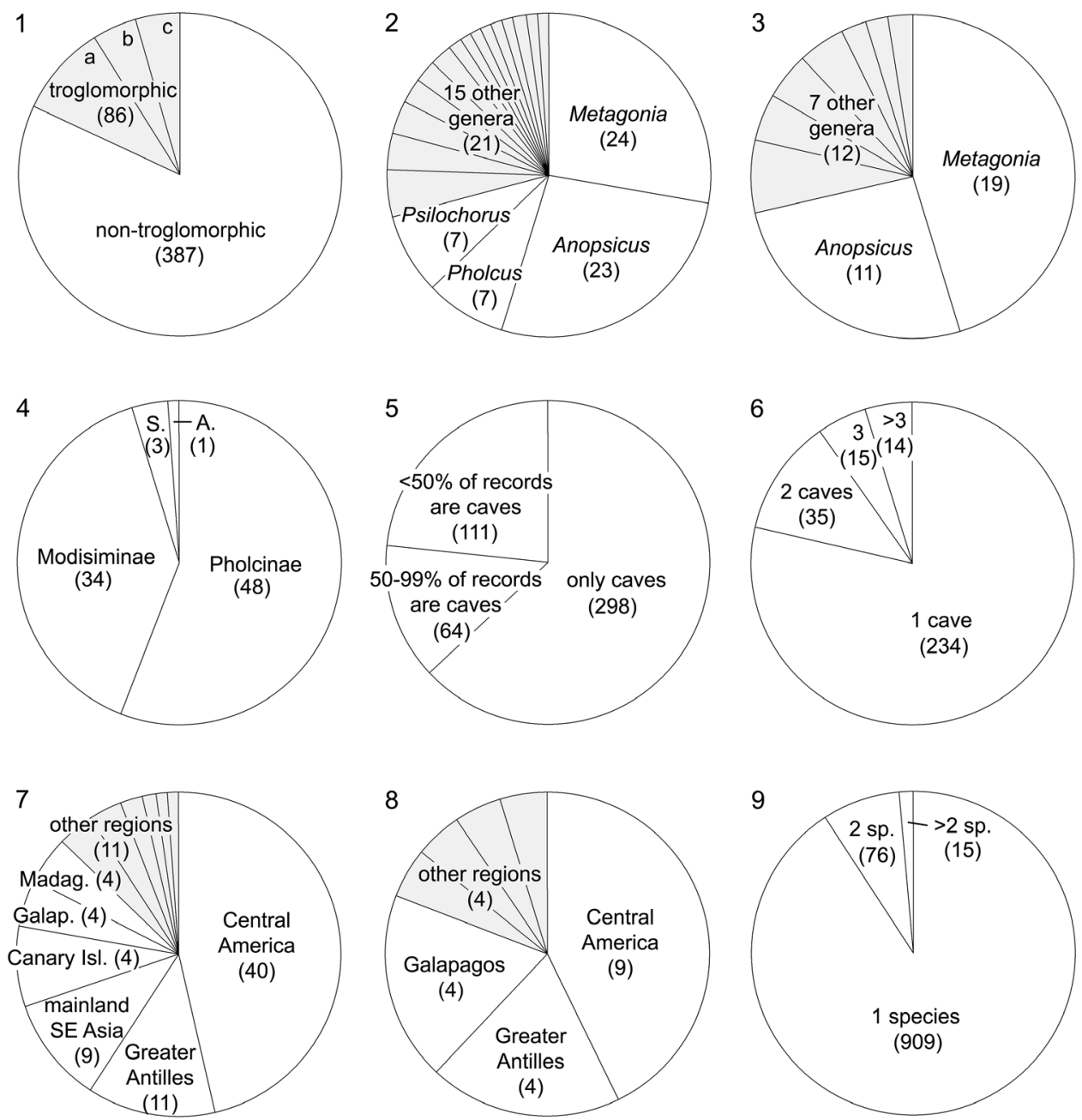

Figures I-9. Main patterns in cave-dwelling pholcid spiders. Numbers in parentheses are usually species numbers ( $\mathbf{I - 8})$, but cave numbers in (9). I Troglomorphic and non-troglomorphic cave-dwelling pholcids; a, eyes normal; b, eyes reduced in size and/or pigment; c, eyes absent $\mathbf{2}$ Generic assignment of the 86 troglomorphic pholcid species $\mathbf{3}$ Generic assignment of the 42 'strongly' troglomorphic species $\mathbf{4}$ Subfamily assignment of the 86 troglomorphic species; S., Smeringopinae; A., Arteminae $\mathbf{5}$ Known habitat of 473 cave-dwelling pholcids 6 Number of caves known to be inhabited by 298 species known from caves only 7 Geographic distribution of the 86 troglomorphic species 8 Geographic distribution of the 21 eyeless species 9 Number of species found in each of 1000 caves.

Metagonia on Cuba, Jamaica, and the Galapagos Islands, all of which are eyeless and have no epigean relatives on these islands (Gertsch 1986, Gertsch and Peck 1992, Pérez and Huber 1999); (2) an undescribed eyeless species on Réunion Island, possibly member of the East African genus Buitinga Huber, 2003 and with no known congener on Réunion (B.A. Huber, unpublished data); (3) the strongly troglomorphic Ossinissa 
justoi (Wunderlich, 1992) on El Hierro (Canary Islands), only representative of the genus, possibly related to two other troglomorphic species on Tenerife currently in Pholcus and not closely related to epigean Pholcus in the Canary Islands (Dimitrov and Ribera 2005, Huber 2011: 367).

\section{Distribution}

The most obvious and striking geographic pattern is the apparent dominance of Mexico. Of the 86 troglomorphic species, 39 (i.e. 45\%) occur in Mexico, followed by Jamaica and the Canary Islands (7 species each), Galapagos Islands, Cuba, Madagascar, and Laos (4 species each). A more biologically meaningful comparison between regions rather than countries gives the same picture (Fig. 7): 40 species in Central America (following the United Nations geoscheme; https://unstats.un.org/unsd/methodology/m49/), followed by the Greater Antilles (11 species) and mainland SE Asia ( 9 species). The same pattern is observed when considering only the most strongly troglomorphic (i.e. eyeless) species: nine of 21 species (i.e. 43\%) occur in Central America (all of them in Mexico) (Fig. 8).

A second striking pattern is the prevalence of islands. Apart from Mexico, most troglomorphic species occur on islands: discounting the 40 Central American troglomorphs, 30 of the remaining 46 troglomorphic species (i.e. 65\%) occur on islands. This apparent bias is even more pronounced when considering only the most strongly troglomorphic (i.e. eyeless) species: ten occur on islands, only two eyeless species are neither Mexican nor from an island (Metagonia diamantina Machado et al., 2011 from Brazil and Belisana khanensis Yao \& Li, 2013 from Laos).

Europe (incl. Turkey) appears like a hotspot in Fig. 10, but this refers to caves inhabited by pholcids (see below) and not to species diversity of troglomorphic pholcid spiders. Only three troglomorphic pholcids are known from Europe: two putative species of Stygopholcus on the Balkan Peninsula and one species of Hoplopholcus in Turkey (Table 1).

\section{Caves and alpha-diversity}

Native species of Pholcidae have been collected from 1000 caves, most of which are located in three geographic regions: Central America and the Caribbean; Dinaric Alps and eastern Mediterranean; and mainland SE Asia including southern China (Fig. 10). In the large majority of these caves (909, i.e. $91 \%$ ) a single representative of Pholcidae has been found (Fig. 9); 76 caves contained two species; only 15 caves were found to contain more than two species. Of the 91 caves with more than one species, 36 (i.e. 40\%) occur in Mexico, followed by Puerto Rico (6 caves), Cuba (5 caves), Brazil, Hispaniola, Crete, and Thailand ( 4 caves each). The highest known diversity has been reported from Puong Cave, Ba Be National Park, Vietnam ( 5 species), followed by Cueva de la Capilla, Tamaulipas, Mexico (4 species) and Cueva Aguas Buenas, Puerto Rico (4 species). 


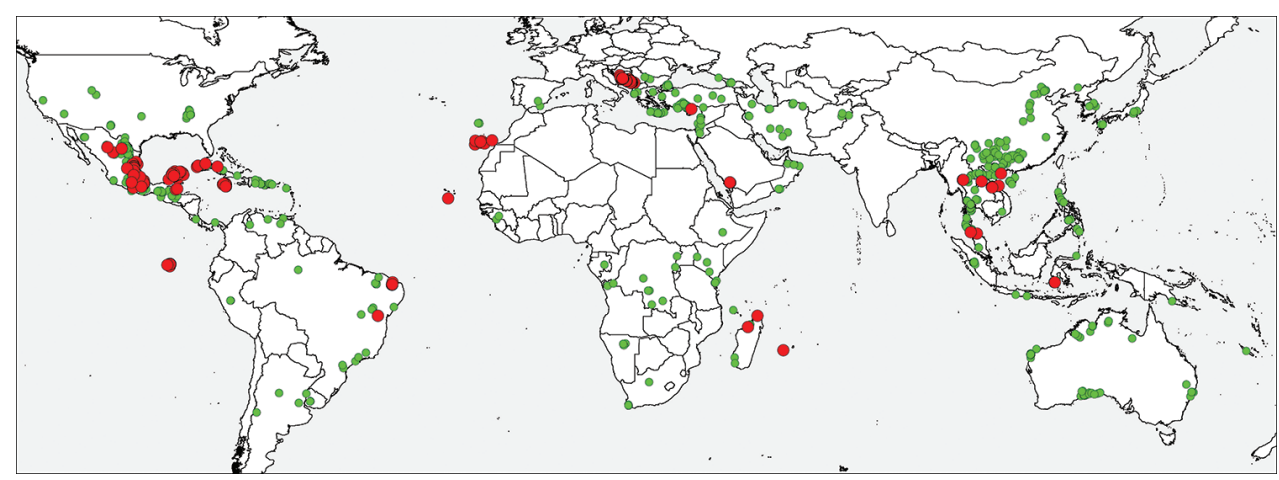

Figure 10. Geographic distribution of 1000 caves in which native pholcid spider species have been found. Green: non-troglomorphic; red: troglomorphic.

\section{Discussion}

\section{Uneven systematic distribution}

One of the most prevalent patterns in subterranean biology is that the large majority of troglomorphic animals belong to a relatively small number of major taxa (e.g., Moldovan 2012, Christiansen 2012). Unsurprisingly, this pattern is also found in Pholcidae. Five of the currently recognized 77 extant genera contain $75 \%$ of the troglomorphic species. To some degree, this might simply result from certain genera being present in cave-rich regions: the genera Anopsicus and Metagonia (that contain the majority of troglomorphic pholcid species) happen to be present in cave-rich countries like Mexico, Jamaica, and Cuba. Genera endemic to, for example, South America may have fewer troglomorphs simply because South America's carbonate outcrop area is much smaller than that of North America including Central America and the Caribbean (Ford and Williams 2007). However, the uneven systematic distribution remains when considering only cave-rich areas. Mexico, for example, is home so several speciesrich pholcid genera in addition to Anopsicus and Metagonia, yet they contain very few troglomorphic species: while 38 of 92 Mexican species in Anopsicus, Metagonia, and Psilochorus, are troglomorphic (i.e. $41 \%$ ), only three of the 76 species in the remaining seven native Mexican genera are troglomorphic (i.e. 4\%).

Part of an answer for this mysterious pattern may come from a recent study on diversification patterns within the family (J. Eberle, D. Dimitrov, A. Valdez-Mondragón, B.A. Huber, unpublished data). Shifts among different microhabitats such as leaf-litter, large sheltered spaces, and undersides of life leaves (i.e. green leaves in the vegetation as opposed to dead leaves in the leaf litter) were not homogeneously distributed among the family but concentrated in two of the five subfamilies: Pholcinae and Modisiminae. This evolutionary ecological flexibility or 'evolvability' was thought to be among the main drivers of species diversification in those two subfamilies. It may also partly account for the uneven systematic distribution of troglomorphisms, where most troglomorphic pholcid species are in Pholcinae and 
Modisiminae (Fig. 4). This might explain why certain species-rich genera that are frequently found in caves, such as Physocyclus in Mexico or Trichocyclus Simon, 1908 in Australia have not evolved troglomorphic species: both belong to Arteminae. On the other hand, it does still not explain the few troglomorphs in some genera of Modisiminae and Pholcinae in cave-rich regions, such as Modisimus Simon, 1893 and Ixchela Huber, 2000 in Mexico, or Belisana Thorell, 1898, Khorata Huber, 2005, and Pholcus in SE Asia.

\section{Uneven geographic distribution}

A second common and equally poorly understood phenomenon is that widespread taxa have troglomorphic representatives in certain geographic regions only (e.g., Deharveng et al. 2012). Pholcidae also follow this trend, with a remarkable concentration of troglomorphic taxa in Mexico, followed by mainland SE Asia and some islands, and very few troglomorphic species in mainland South America and mainland Africa, and none in Australia. In analogy to the argument above, this might simply result from the fact that certain taxa that are particularly preadapted to subterranean life happen to be present in certain regions and not in others. For example, Anopsicus has many troglomorphic species and happens to be restricted to Central America and the Greater Antilles. The case of Metagonia seems to contradict this idea. Metagonia is widely distributed from Argentina to the U.S.A., with similar numbers of species available from South America (incl. the Galapagos Islands) (58) and North America (incl. Central America and the Caribbean) (57). Troglomorphic species in Metagonia, however, are very unevenly distributed: only five species in South America versus 19 species in North America.

Several factors are likely to contribute to the apparent uneven geographic distribution: (1) The uneven distribution of carbonate outcrop (see above); it has been argued before that the best predictor of subterranean species diversity is the availability of habitat expressed by the number of caves in a region (Christman and Culver 2001, Culver et al. 2003). (2) The lower tendency for high energy caves to contain troglomorphic species (see Tropical versus temperate caves below). (3) Research biases. The latter also affects the uneven systematic distribution above, but is difficult to quantify. It includes collectors' as well as taxonomists' biases. India, for example, does not have a single record of a cave-dwelling pholcid, but this may simply result from the fact that India is among the most poorly studied countries regarding pholcid spiders in general. Mexican pholcids, on the other hand, have for many decades attracted the focused attention of collectors, and a single taxonomist (Willis J. Gertsch) has devoted a number of large papers to Mexican pholcids, with particular attention to cave-dwelling species (Gertsch 1971, 1973, 1977, 1982, 1986). Without Gertsch, Mexico would currently count only six troglomorphic pholcid species instead of 39. Some countries rich in troglomorphic pholcids may simply not have had the lucky combination of skilled and enthusiastic collectors and a dedicated taxonomist. 
Surprising and difficult to explain is the over-representation of troglomorphic species on islands. This does not seem to be a widespread pattern in subterranean animals; there is no good reason to assume that collectors and taxonomists have been biased towards working on island faunas; and the ages of the islands vary widely from a few million years (Galapagos, Canaries, Réunion) to $>100$ million years (Greater Antilles, Cape Verde, Madagascar).

\section{Tropical versus temperate caves}

Pholcidae have most of their species diversity in the tropics and subtropics and thus do not contribute directly to the debate about the apparent higher number of troglomorphic species in temperate rather than in tropical regions. The historical bias of speleology and taxonomy towards European and North American cave faunas is uncontested (cf. Moldovan 2012, Deharveng and Bedos 2012, Galláo and Bichuette 2018). Nevertheless, for certain taxa such as most insects the trend towards a relatively low diversity in tropical caves does not seem to disappear with a more comprehensive study of tropical faunas. On the other hand, spiders and arachnids in general, may not follow this pattern but, on the contrary, occupy in the tropics the predatory positions that are in temperate caves held by beetles and other arthropods (Reddell 2012). However, a comprehensive review of subterranean arachnids or just spiders has apparently never been attempted.

\section{Outlook and promising projects}

Subterranean pholcid diversity is still poorly known in most parts of the world and it will clearly need massive long-time efforts by collectors and taxonomists to substantially change this. This section focuses instead on a few particular questions that seem relatively easy to answer within a limited period of time and with reasonable effort.

Troglomorphisms. There is basically no information in the literature about troglomorphisms in pholcid spiders beyond simple qualitative remarks about those troglomorphisms that are easily observed (Figs 11-14): eye reduction, pigment loss, and leg elongation. Theory predicts that several additional traits may be affected. For example, egg size is expected to increase while egg number is expected to decrease; the concentration of sensilla is expected to increase; excitement (reaction to disturbance) is expected to decrease; and longevity and body size are expected to increase (Culver 1982, Hüppop 2012). For several species the classification as troglomorphic or not is quite ambiguous, and this introduces noise in the analyses. A quantification of troglomorphisms would clarify limits and probably reveal interesting patterns. For example, a simple plot of relative leg lengths (tibia 1/carapace width) in 55 species of Anopsicus (taken from Gertsch 1982) shows a slight increase in leg length in species found only in caves compared to epigean species, but a strong increase in species with reduced 
eyes or without eyes. Individual taxa offer additional possibilities to study particular troglomorphisms. For example, the South American Mesabolivar aurantiacus (MelloLeitão, 1930) is sexually dimorphic in coloration, with males (in particular large males) having the third femora bright red rather than dark brown. In a recently discovered cave population in the Brazilian state Amazonas, the male third femora showed little or no difference to other (and female) femora (Huber 2018). The significance of this sexual dimorphism remains unknown. Another potential troglomorphism concerns web structure. Food shortage is considered a major selective pressure responsible for troglomorphisms (Hüppop 2012, Poulson 2012), and prey-capturing devices such as spider webs should in theory be affected. This has never been studied in any pholcid (nor, to my knowledge, in any spider), but the web of a recently discovered Brazilian Metagonia species with evanescent eyes was indeed very different from 'usual' webs of Metagonia and other pholcids (B.A. Huber, unpublished data): instead of representing a sheet with tumble lines (suitable for intercepting flying prey) it included an exceptionally high number of gum-foot lines (suitable for catching walking prey; cf. Japyassú and Macagnan 2004) (Figs 15-16).

Habitats of apparently cave-restricted species. Of the 473 pholcid species found in caves, 218 have only been found in caves yet do not show any obvious troglomorphisms. In theory, many of them might indeed be specialized to the cave entrance ecotone, but the more plausible hypothesis is that the actual habitat of most of these species is in fact the shallow subterranean habitat (cf. Deeleman-Reinhold and Deeleman 1980, Culver and Pipan 2009). Good candidates to test this hypothesis are (1) non-troglomorphic species with numerous cave-records but no records so far from outside caves (e.g., Modisimus boneti Gertsch, 1971; Metagonia blanda Gertsch, 1973; Hoplopholcus trakyaensis Demircan \& Topçu, 2017; Uthina saiyokensis Yao \& Li, 2016; Ixchela pecki (Gertsch, 1971); and Modisimus mitchelli Gertsch, 1971); and (2) troglomorphic species that are known from numerous caves each (see examples above).

The genus Anopsicus. In Central America and the Caribbean, the genus Anopsicus offers an ideal opportunity to study a large radiation that includes both epigean and hypogean species. Judging from the small ranges of epigean species, it seems likely that hypogean species have evolved repeatedly from epigean ancestors, but a phylogeny of the genus is not available.

The genus Aymaria. On the Galapagos Islands, four nominal species of Aymaria Huber, 2000 are currently recognized, two of them epigean (on most or all islands), two hypogean and eyeless (on Santa Cruz and Floreana). The genitalia of all four 'species' appear essentially indistinguishable, and I have argued previously that only two species might be present, one epigean, one hypogean (Huber 2000). In the meantime, several species in a range of major taxa are known to include epigean and troglomorphic hypogean populations (e.g., Verovnik et al. 2004, Fong 2012, Gross 2012), and interspecific variation in troglomorphic traits has also been found in spiders (Shear 1978; further references in Mammola and Isaia 2017). As a consequence, the null hypothesis should be that only a single species of Aymaria occurs on the Galapagos Islands. Beyond species limits, Aymaria on Galapagos offers the opportunity to study 

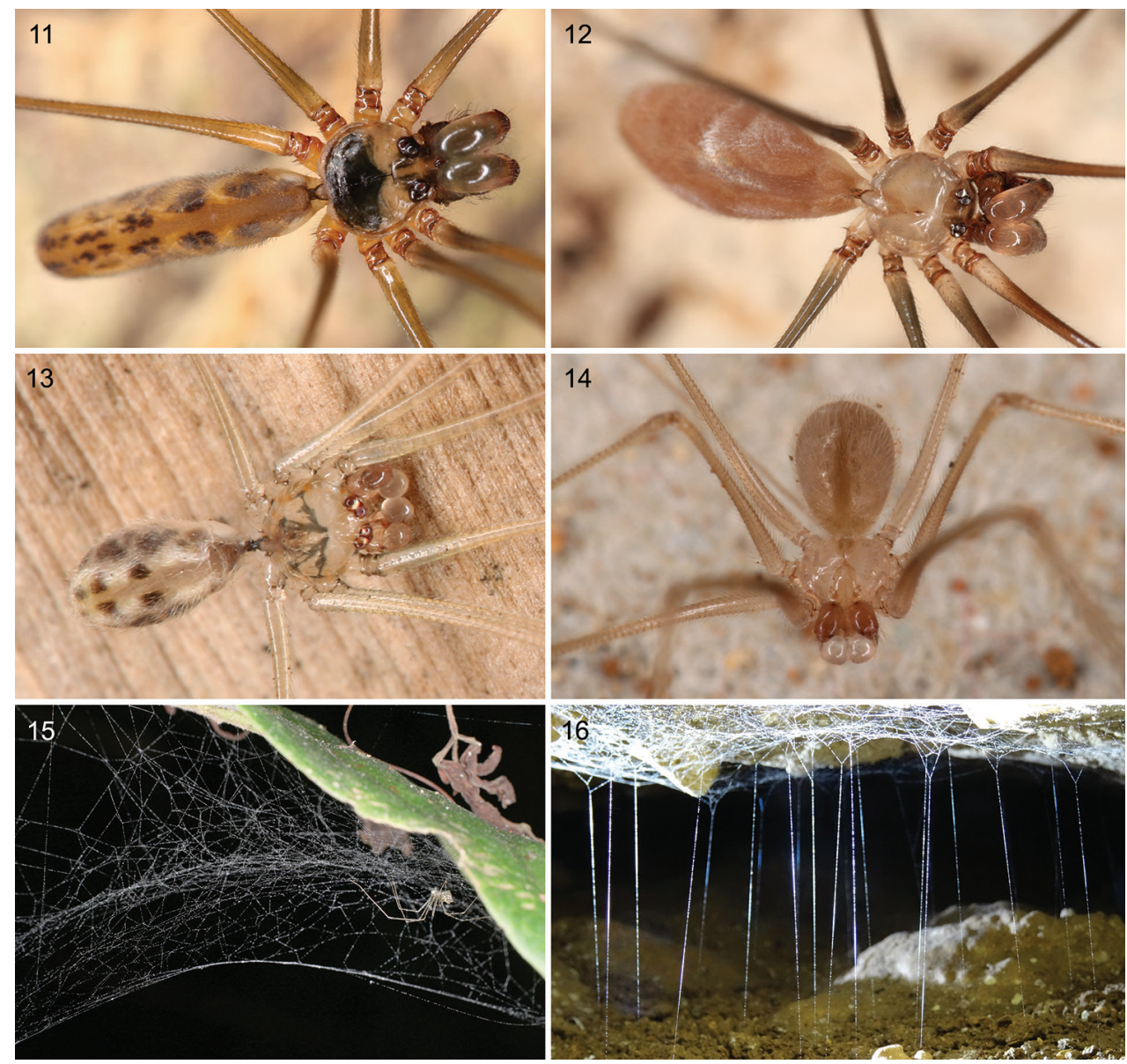

Figures II-16. Examples of non-troglomorphic and troglomorphic pholcid spiders and their webs. I I-I 2 Two undescribed species of Uthina from Bali and Sulawesi; note smaller eyes and paler color in cave-dwelling species ( I 2). I3-I4 Two undescribed species of Metagonia from Brazil (Pernambuco, Rio Grande do Norte); note evanescent eyes and pale coloration in cave-dwelling species (I4). I5-16 'Typical' pholcid web of epigean Metagonia bonaldoa $\mathbf{I 5}$ domed sheet with tumble lines above sheet; Brazil, Santa Catarina), and unusual web of cave-dwelling Metagonia potiguar $\mathbf{1 6}$ sheet attached to rock surface and many vertical gum-foot lines; Brazil, Rio Grande do Norte). Photos BAH.

a case where strong troglomorphism has evolved relatively rapidly, as judged from the age of the islands $(\sim 1-2.5 \mathrm{My}$ for Santa Cruz and Floreana) and the apparent lack of genitalic differences.

Sympatric species. In 91 caves, two or more species of Pholcidae were found to coexist, but beyond anecdotal observations there is almost nothing known about interspecific competition and niche partitioning. The only quantitative data describe spatial segregation in Micropholcus piaui Huber et al., 2014 and Mesabolivar spinulosus (Mello-Leitão, 1939) in a cave in Brazil (by L.S. Carvalho, reported in Huber et al. 
2014). Several alternatives to spatial segregation are plausible and have been reported in other spiders (Arnedo et al. 2007). Of particular interest are caves with multiple species of the same genus (e.g. Hanging Gardens Cave in California with three species of Psilochorus; Puong Cave in Vietnam with three species of Khorata).

\section{Conclusions}

Pholcid spiders are common inhabitants of tropical and subtropical caves, and many species in several genera have evolved strong troglomorphisms. Despite of some 'noise' in the data (e.g., uncertainty in classifying some species as troglomorphic or not; uncertainty of exact geographic coordinates of some caves; uncertainty in taxonomic status of some 'species') a few general conclusions can be drawn:

- A total of 473 native pholcid species have been found in caves. This means that about $25 \%$ of the species currently known to exist are either occasionally or exclusively found in caves. Most cave-dwelling pholcids are not troglomorphic and thus presumably not obligate cave-dwellers but 'troglophiles'.

- About 86 species of troglomorphic pholcid species have been found, including 21 eyeless species and 21 species with strongly reduced eyes. Troglomorphic pholcids exist in 20 of currently 77 extant genera, but Anopsicus and Metagonia alone include almost half of the troglomorphic species.

- Mexico is by far the richest country in terms of troglomorphic pholcids, followed by several islands (Greater Antilles, Galapagos, Canaries, Réunion, Cape Verde, Madagascar, Sulawesi, New Guinea) and mainland SE Asia. The apparent dominance of Mexico may partly be due to collectors' and taxonomists' biases.

- Native pholcid spiders have been found in 1000 caves. In most of these caves, only one pholcid species has been found, but two and more species (up to five) have been found in 91 caves.

- Most troglomorphic pholcids belong to two subfamilies (Pholcinae, Modisiminae), very few belong to Smeringopinae and Arteminae, and none to Ninetinae. This is in agreement with the recent finding that within Pholcidae, microhabitat changes in general are concentrated in Modisiminae and Pholcinae.

\section{Acknowledgements}

I am grateful to colleagues for help with georeferencing localities: L.S. Carvalho, P. Oromí, M. Pavlek, P. Sprouse, and A. Váldez-Mondragón. I thank C. Hamilton and an anonymous reviewer for their constructive criticism and for their help in improving the manuscript. Financial support was provided by the German Research Foundation (DFG, project HU 980/11-1). 


\section{References}

Arnedo MA, Oromí P, Múrria C, Macías-Hernández N, Ribera C (2007) The dark side of an island radiation: Systematics and evolution of troglobitic spiders of the genus Dysdera Latreille (Araneae:Dysderidae) in the Canary Islands. Invertebrate Systematics 21: 623-660. https://doi.org/10.1071/IS07015

Christiansen K (2012) Morphological adaptations. In: White WB, Culver DC (Eds) Encyclopedia of Caves (2 $2^{\text {nd }}$ edn). Academic Press, 517-528. https://doi.org/10.1016/B978-0-12383832-2.00075-X

Christman MC, Culver DC (2001) The relationship between cave biodiversity and available habitat. Journal of Biogeography 28: 367-380. https://doi.org/10.1046/j.13652699.2001.00549.x

Culver DC (1982) Cave Life - Evolution and Ecology. Harvard University Press, Cambridge, MA. https://doi.org/10.4159/harvard.9780674330214

Culver DC, Pipan T (2009) Superficial subterranean habitats - gateway to the subterranean realm? Cave and Karst Science 35: 5-12.

Culver DC, Sket B (2000) Hotspots of subterranean biodiversity in caves and wells. Journal of Cave and Karst Studies 62: 11-17.

Culver DC, Christman MC, Elliott WR, Hobbs III HH, Reddell JR (2003) The North American obligate cave fauna: regional patterns. Biodiversity and Conservation 12: 441-468. http://dx.doi.org/10.1023/A:1022425908017

Culver DC, Wilkens H (2000) Critical review of the relevant theories of the evolution of subterranean animals. In: Wilkens H, Culver DC, Humphreys WF (Eds) Subterranean Ecosystems. Elsevier, Amsterdam, 381-398.

Deeleman-Reinhold CL, Deeleman PR (1980) Remarks on troglobitism in spiders. In: Gruber J (Ed.) Proceedings of the $8^{\text {th }}$ International Congress of Arachnology, Vienna. H. Egermann, Vienna: 433-438.

Deharveng L, Bedos A (2012) Diversity patterns in the tropics. In White WB and Culver DC (Eds). Encyclopedia of Caves. Second edition. Academic Press: 238-250. https://doi. org/10.1016/B978-0-12-383832-2.00032-3

Deharveng L, Gibert J, Culver DC (2012) Diversity patterns in Europe. In: White WB, Culver DC (Eds) Encyclopedia of Caves (2 $2^{\text {nd }}$ edn). Academic Press, 219-228. https://doi. org/10.1016/B978-0-12-383832-2.00030-X

Dimitrov D, Ribera C (2005) Description of Ossinissa, a new pholcid genus from the Canary Islands (Araneae: Pholcidae). Zootaxa 982: 1-13. http://dx.doi.org/10.11646/zootaxa.982.1.1

Dong T, Zheng G, Yao Z, Li S (2017) Ten new species of the spider genus Pholcus Walckenaer, 1805 (Araneae, Pholcidae) from Southeast Asia. Zootaxa 4306: 339-369. http://dx.doi. org/10.11646/zootaxa.4306.3.3

Ferreira RL, Souza MFVR, Machado EO, Brescovit AD (2011) Description of a new Eukoenenia (Palpigradi: Eukoeneniidae) and Metagonia (Araneae: Pholcidae) from Brazilian caves, with notes on their ecological interactions. Journal of Arachnology 39: 409-419. https:// doi.org/10.1636/Ha11-03.1 
Foelix R (2011) Biology of Spiders ( $3^{\text {rd }}$ edn). Oxford University Press, New York.

Fong DW (2012) Gammarus minus: a model system for the study of adaptation to the cave environment. In: White WB, Culver DC (Eds) Encyclopedia of Caves ( $2^{\text {nd }}$ edn). Academic Press, 341-347. https://doi.org/10.1016/B978-0-12-383832-2.00047-5

Ford DC, Williams PW (2007) Karst Hydrogeology and Geomorphology. Wiley, Chichester. https://doi.org/10.1002/9781118684986

Galláo JE, Bichuette ME (2018) Brazilian obligatory subterranean fauna and threats to the hypogean environment. ZooKeys 746: 1-23. http://dx.doi.org/10.3897/zookeys.746.15140

Gertsch WJ (1971) A report on some Mexican cave spiders. Association for Mexican Cave Studies, Bulletin 4: 47-111.

Gertsch WJ (1973) A report on cave spiders from Mexico and Central America. Association for Mexican Cave Studies, Bulletin 5: 141-163.

Gertsch WJ (1977) Report on cavernicole and epigean spiders from the Yucatan Peninsula. Association for Mexican Cave Studies, Bulletin 6: 103-131.

Gertsch WJ (1982) The spider genera Pholcophora and Anopsicus (Araneae, Pholcidae) in North America, Central America and the West Indies. Association for Mexican Cave Studies, Bulletin 8: 95-144.

Gertsch WJ (1986) The spider genus Metagonia (Araneae: Pholcidae) in North America, Central America, and the West Indies. Texas Memorial Museum, Speleological Monographs 1:39-62.

Gertsch WJ, Peck SB (1992) The pholcid spiders of the Galápagos Islands, Ecuador (Araneae: Pholcidae). Canadian Journal of Zoology 70: 1185-1199. https://doi.org/10.1139/z92166

Grandcolas P, Nattier R, Trewick SA (2014) Relict species: A relict concept? Trends in Ecology \& Evolution 29: 655-663. https://doi.org/10.1016/j.tree.2014.10.002

Gross JB (2012) The complex origin of Astyanax cavefish. BMC Evolutionary Biology 12: 105. https://doi.org/10.1186/1471-2148-12-105

Howarth FG (1980) The zoogeography of specialized cave animals: a bioclimatic model. Evolution 34: 394-406. https://doi.org/10.1111/j.1558-5646.1980.tb04827.x

Hüppop K (2012) Adaptation to low food. In: White WB, Culver DC (Eds) Encyclopedia of Caves ( $2^{\text {nd }}$ edn). Academic Press, 1-9. https://doi.org/10.1016/B978-0-12-3838322.00001-3

Huber BA (2005a) High species diversity, male-female coevolution, and metaphyly in Southeast Asian pholcid spiders: the case of Belisana Thorell 1898 (Araneae, Pholcidae). Zoologica 155: 1-126.

Huber BA (2005b) Revision of the genus Spermophora Hentz in Southeast Asia and on the Pacific Islands, with descriptions of three new genera (Araneae: Pholcidae). Zoologische Mededelingen 79-2: 61-172.

Huber BA (2011) Revision and cladistic analysis of Pholcus and closely related taxa (Araneae, Pholcidae). Bonner zoologische Monographien 58: 1-509.

Huber BA (2018) The South American spider genera Mesabolivar and Carapoia (Araneae, Pholcidae): new species and a framework for redrawing generic limits. Zootaxa 4395: 1-178. https://doi.org/10.11646/zootaxa.4395.1.1 
Huber BA, Carvalho LS, Benjamin SP (2014) On the New World spiders previously misplaced in Leptopholcus: molecular and morphological analyses and descriptions of four new species (Araneae, Pholcidae). Invertebrate Systematics 28: 432-450. http://dx.doi.org/10.1071/ IS13050

Huber BA, Pérez GA (2001) A new genus of pholcid spiders (Araneae: Pholcidae) endemic to Western Cuba, with a case of female genitalic dimorphism. American Museum Novitates 3329: 1-23. http://dx.doi.org/10.1206/0003-0082(2001)329<0001:ANGOPS>2.0.CO;2 Japyassú HF, Macagnan CR (2004) Fishing for prey: the evolution of a new predatory tactic among spiders (Araneae, Pholcidae). Revista de Etología 6: 79-94.

Klaus S, Mendoza JCE, Liew JH, Plath M, Meier R, Yeo DCJ (2013) Rapid evolution of troglomorphic characters suggests selection rather than neutral mutation as a driver of eye reduction in cave crabs. Biology Letters 9: 20121098. http://dx.doi.org/10.1098/rsbl.2012.1098

Krishnan J, Rohner N (2016) Cavefish and the basis for eye loss. Philosophical Transactions of the Royal Society, Series B 372: 20150487. http://dx.doi.org/10.1098/rstb.2015.0487

Liu W, Golovatch S, Wesener T, Tian M (2017) Convergent evolution of unique morphological adaptations to a subterranean environment in cave millipedes (Diplopoda). PLoS ONE 12: e0170717. https://doi.org/10.1371/journal.pone.0170717

Machado ÉO, Ferreira RL, Brescovit AD (2011) A new troglomorphic Metagonia Simon, 1893 (Araneae, Pholcidae) from Brazil. Zootaxa 3135: 59-62.

Mammola S, Isaia M (2017) Spiders in caves. Proceedings of the Royal Society, Series B 284: 20170193. http://dx.doi.org/10.1098/rspb.2017.0193

Mammola S, Cardoso P, Ribera C, Pavlek M, Isaia M (2017) A synthesis on cave-dwelling spiders in Europe. Journal of Zoological Systematics and Evolutionary Research (2017): 1-16. https://doi.org/10.1111/jzs.12201

Millot J (1946) Les pholcides de Madagascar (Aranéides). Mémoires du Muséum national d'histoire naturelle (NS) 22(3): 127-158.

Moldovan OT (2012) Beetles. In: White WB, Culver DC (Eds) Encyclopedia of Caves (2 ${ }^{\text {nd }}$ edn). Academic Press, 54-62. https://doi.org/10.1016/B978-0-12-383832-2.00008-6

Pérez GA, Huber BA (1999) Metagonia debrasi n. sp., the first species of the genus Metagonia Simon in Cuba (Pholcidae, Araneae). Revue Arachnologique 13: 69-72.

Poulson TL (2012) Food sources. In: White WB, Culver DC (Eds) Encyclopedia of Caves (2 ${ }^{\text {nd }}$ edn). Academic Press, 323-334. https://doi.org/10.1016/B978-0-12-383832-2.00045-1

Protas M, Jeffery WR (2012) Evolution and development in cave animals: from fish to crustaceans. Wiley Interdisciplinary Reviews. Developmental Biology 1: 823-845. http://doi. org/10.1002/wdev.61

Reddell JR (2012) Spiders and related groups. In: White WB, Culver DC (Eds) Encyclopedia of Caves (2 ${ }^{\text {nd }}$ edn). Academic Press, 786-797. https://doi.org/10.1016/B978-0-12383832-2.00114-6

Shear WA (1978) Taxonomic notes on the armored spiders of the families Tetrablemmidae and Pacullidae. American Museum Novitates 2650: 1-46.

Souza Silva M, Ferreira RL (2015) Cave invertebrates in Espírito Santo state, Brazil: a primary analysis of endemism, threats and conservation priorities. Subterranean Biology 16: 79-102. https://doi.org/10.3897/subtbiol.16.5227 
Verovnik R, Sket B, Trontelj R (2004) Phylogeography of subterranean and surface populations of water lice Asellus aquaticus (Crustacea: Isopoda). Molecular Ecology 13: 1519-1532. https://doi.org/10.1111/j.1365-294X.2004.02171.x

White WB (1988) Geomorphology and Hydrology of Karst Terrains. Oxford University Press, New York.

White WB, Culver DC [Eds] (2012) Encyclopedia of Caves (2 ${ }^{\text {nd }}$ edn). Academic Press.

World Spider Catalog (2018) World Spider Catalog. Natural History Museum Bern. http:// wsc.nmbe.ch [version 19.0, accessed on 30 April 2018]

Wunderlich J (1992) Die Spinnen-Fauna der Makaronesischen Inseln. Taxonomie, Ökologie, Biogeographie und Evolution. Beiträge zur Araneologie 1: 1-619.

Wunderlich J (1999) Eine bisher unbekannte cavernicole Art der Zitterspinnen von La Palma, Kanarische Inseln (Arachnida: Araneae: Pholcidae). Entomologische Zeitschrift 109: 71-73. Yao Z, Li S (2013) New and little known pholcid spiders (Araneae: Pholcidae) from Laos. Zootaxa 3709: 1-51. http://dx.doi.org/10.11646/zootaxa.3709.1.1

Yao Z, Pham D, Li S (2015) Pholcid spiders (Araneae: Pholcidae) from northern Vietnam, with descriptions of nineteen new species. Zootaxa 3909: 1-82. http://dx.doi.org/10.11646/ zootaxa.3909.1.1 